\title{
The Role of E-Education in Preserving Educational Outcomes During Covid-19 Pandemic
}

\author{
Dr. Yousef Almoslamani \\ Collage of Education, Ha'il University, PO box 2440, Ha'il 55421, Saudi Arabia
}

\begin{abstract}
This study aims to examine the role of e-education in preserving educational outcomes during the Covid-19 pandemic and to explore factors that were associated with these outcomes. A descriptive cross-sectional study was conducted between August and September 2020. A sample of Saudi Electronic University (SEU) students was asked to participate in this study. The study questionnaire is composed of seven main domains; demographics domain, attitudes towards e-education, others influence on e-education perception, contents of education and participation in the online discussion, challenges of e-education, effects of e-education, and finally a comparison between e-education and traditional education. One hundred and thirty eight students participated in this survey. The students reported that e-education is appropriate and they indicated positive views towards using e-education tools in their daily study. The majority of study participants reported low participation in an online discussion. In addition, the participants reported limited ability to overcome e-education challenges. The participants stated that e-education improves their overall performance. The majority of the students reported that e-education is superior to the traditional educational methods and half of the participants reported that they would recommend e-education to others. Based on study results, it is recommended to find motivation and monitoring tools to encourage the students to participate more in the online discussion, which could eventually enhance the achievement of students enrolled in the e-education. In addition, more support is needed to eliminate challenges associated with the Covid19 pandemic and maintain students' positive view towards the e-education process.
\end{abstract}

Keywords: e-education, Distance learning; Educational technology, Covid-19 Pandemic, Saudi Arabia

DOI: $10.7176 / \mathrm{JEP} / 11-32-15$

Publication date: November $30^{\text {th }} 2020$

\section{Introduction}

In December 2019, a new viral infection appeared in the Wuhan providence in China and it quickly spread all over the world (Sapkota \& Narayangarh, 2020). The World Health Organization (WHO) announce a global pandemic status in March 2020 (Khalil et al., 2020). The official name of this new virus is '2019 novel coronavirus' or Covid19. It has disrupted normal life activities for millions of people worldwide, including educational activities (Alqahtani \& Rajkhan, 2020; Martins et al., 2020). Lockdowns were announced in several countries and regions. Universities and schools were forced to shut down and switch to distance education or e-education (Kaur et al., 2020; Rajhans et al., 2020). Although e-education has become a well-known phenomenon in the modern era, this unplanned and sudden switch to e-education was an excellent opportunity to examine the large-scale effects of eeducation on educational outcomes (Alqahtani \& Rajkhan, 2020; Khalil et al., 2020).

In Saudi Arabia, the first Covid-19 case was reported in March 2020 and the lockdown measures were implemented in the same month (KSA, 2020; Network, 2020; WorldAware, 2020). The Saudi government closed all traditional face-to-face educational institutes. The only available option to continue the educational process was e-education (Almaghaslah \& Alsayari, 2020; "Coronavirus Outbreak Forces Arab Countries to Consider LongIgnored Online Education," 2020). Meanwhile, the Saudi Electronic University (SEU) is a well know long-term reputable e-education institution, established back in 2012 (Alsadoon, 2020; Bugis, 2020). Since the SEU was already providing an e-education blinded curriculum, the Covid-19 pandemic has not led to significant disruption in its activity. On the contrary, it started a new opportunity to expand the e-educational activities to a broader targeted population (W. Saudi Electronic University, n.d.). However, the effects of Covid-19 on educational outcomes were not explored on SEU students.

Nowadays, the benefits and advantages of e-education reached a point that is not a matter of argument and debate anymore (Boateng, 2015). However, the vast majority of studies that examined the benefits of e-education were conducted in a period when this method was optional, unlike the situation with Covid-19 when it becomes the only option for educational activities. Therefore, it is crucial to explore the effects of e-education on education outcomes in Covid-19 affected areas.

Although there is no consensus on a definition for e-education, the following definition is widely used in the literature: E-education is referred to as the use of electronic tools, applications and telecommunication to provide, maintain, and improve the educational process and involves discussions between students and teachers using electronic and web materials and teaching, and involves communication between learners and teachers utilizing online content (Alfawaz \& Yamin, 2020; Baticulon et al., 2020; ESRI et al., 2020, p. 19).

This study aims to examine the role of e-education in preserving educational outcomes during the Covid-19 
pandemic and to explore factors that were associated with these outcomes.

\section{Methodology}

This descriptive cross-sectional study was conducted between August and September 2020. A convenient sample of Saudi Electronic University (SEU) students was asked to participate in this study. Inclusion criteria were any student who was enrolled at any of the undergraduate or postgraduate programs at the time of data collection. Exclusion criteria were those who refused to give informed consent on participation in this study.

The study questionnaire was based on a modified version of Devisakti \& Ramayah and Diab \& Elgahsh questionnaires (Table I). The study questionnaire is composed of seven main domains; demographics domain, attitudes towards e-education, others influence on e-education perception, contents of education and participation in the online discussion, challenges of e-education, effects of e-education, and finally a comparison between eeducation and traditional education (Devisakti \& Ramayah, 2019; Diab \& Elgahsh, 2020).

The study invitation was sent by WhatsApp and Facebook groups to potential participants. The data was collected electronically on Google Forms, then exported as an Excel sheet.

The questionnaire included a short briefing about the nature of the study and the procedures of filling out the questionnaire. An online written, voluntary informed consent was obtained from all study participants. No identifying data were collected in the questionnaire and this study was according to SEU ethical regulations for studies involving human participants. It was conducted according to the Declaration of Helsinki (Williams, 2008).

The anonymous survey data were numerically coded in an Excel sheet (Microsoft Corp., Redmond, WA, USA). The data was imported into an SPSS statistical spreadsheet (Statistical Data Analysis Software, SPSS version 23.0) and analyzed. Descriptive statistics analysis of the demographic characteristics of the study participants was prepared. The five-point Likert scale data were expressed as means \pm standard deviation (SD). The students' response was recorded on from 1 'strongly disagree' to 5 'strongly agree'. The overall mean score was calculated by the summation of all scores and converting the number into a percentage. If the overall score was more than $50 \%$ then it was considered as a positive perception towards e-education. Data were interpreted as statistically significant when p-value $<0.05$.

The internal consistency coefficients (reliability test) were adequate for the questionnaire. The internal consistency (Cronbach's alpha) of the questionnaire was .714. This Cronbach's alpha value is considered adequate because they exceed the threshold of 0.6 (Zhong, 2020).

\section{Results}

One hundred and thirty eight students participated in this survey. Almost $60 \%$ of the study participants were male students and around half of the participants were between 18 and 20 years old. The characteristics of the study participants are described in Table 2.

Both male and female students reported that e-education is appropriate with a mean score of $2.9 \pm 1.2$ and $2.7 \pm 1.2$, respectively. Male students were more confident in using e-education tools $(2.5 \pm 1.4)$ compared to female students $(2.2 \pm 1.5)$, but the difference between the two genders was not statistically significant (p-value 0.181$)$. Similarly, male and female participants reported positive views towards using e-education tools in their daily study with a mean score of $2.7 \pm 1.1$ and $2.6 \pm 1.3$, respectively. On the other hand, encouragement and support from others vary greatly; the encouragement and support ranged from $2.5 \pm 1.4$ scores for support received by male students from university employees to $1.9 \pm 1.4$ score for encouragement of female students by family members.

Meanwhile, female students reported that the e-education contents are informative with a mean score of $2.7 \pm 1.3$ compared with a mean score of $2.3 \pm 1.4$ for male students; however, the mean difference between the two genders was not statistically significant. Nonetheless, both genders reported low participation in an online discussion. Also, the participants reported limited ability to overcome e-education challenges yet female students reported a score of $2.6 \pm 1.5$ for finishing registered courses and male students reported a $2.3 \pm 1.4$ score with no statistical significant difference between the two genders.

Undoubtedly, male and female participants reported that e-education improves their overall performance, with a mean score of $3.0 \pm 1.2$ and 3.1 \pm 1.1 , respectively, while the reported encouragement of e-education for the exploration of additional information in the area of study had a mean score of only $1.8 \pm 1.5$ between female students. The reported encouragement of e-education for time management was limited for both genders. Almost half of the students from both genders agreed that the e-education decreases students' educational expenses.

The majority of the students reported that e-education is superior to the traditional educational methods and half of the participants reported that they would recommend e-education to others. Table 3 and Figure 1 demonstrate the details of students' mean scores towards e-education.

Four out of each ten participants reported a positive perception towards e-education. Around one-third of participants between 18 and 20 years old had positive perception compared with half of the participants $23+$ years old. Both genders were almost equally divided between positive and negative perceptions towards e-education and the difference was not statistically significant. While the positive perception ranged between $35.1 \%$ between 
students, using e-education for less than an hour per week to $51.4 \%$ between students who use e-education 1 to 7 hours per week. Table 4 describes the overall perception of the students towards e-education.

\section{Discussion}

This study provides an essential insight into the e-education outcomes during the Covid-19 pandemic. One of the most prominent highlights of this study is that it showed that despite all the challenges that were associated with the pandemic and the lockdown measures, the majority of the students still believe that e-education is superior to traditional educational methods. This finding is in line with Baticulon et al. and Dodiya et al., reporting that the participants perceive e-education as a better alternative for classical or traditional educational methods (Baticulon et al., 2020; Dodiya et al., 2019).

Although the current study failed to identify any gender difference in the perceptions towards e-education, this was, surprisingly, in contrast to findings of a previous study in Saudi Arabia that reported female students to have more favorable views towards e-education and remote learning in general (Alfawaz \& Yamin, 2020). These differences in gender perception between the two studies could be related by the underrepresentation of female students in the current research and to lockdown measures that could have some impact on gender roles and gender dynamics (Betron et al., 2020).

The majority of SEU students reported that the SEU academic employees were supportive of e-education. This was an expected result since the SEU is one of the pioneer public universities in Saudi Arabia and the Middle East Region in e-education, blending learning and innovation in the educational process (S. Saudi Electronic University, 2020). Alqahtani \& Rajkhan's study in Saudi Arabia demonstrated that the support of the academic team and educational managers are crucial to reaching a positive educational outcome (Alqahtani \& Rajkhan, 2020). Similarly, Bayeck and Lumadi emphasized the importance of teachers' support for the success of eeducational activities (Bayeck, 2016; Lumadi, 2013).

Less than half of the current study participants reported that they contribute to online discussions. This is a low level of involvement in online discussions could be considered as a lost opportunity since those discussions are an essential part of the educational process and exchange of ideas (Linjawi et al., 2012; Nguyen \& Huynh, 2020). Perhaps this low usage level of online discussion forums could be due to the Covid-19 pandemic effect on the communication in general and its social isolation consequences (Taunton, 2020). Alawamleh et al. reported a similar communication challenge in a recently published study about the effect of Covid-19 on the online learning process (Alawamleh et al., 2020).

In addition, the majority of participants in the current study reported that it was not easy for them to overcome the challenges of e-education. Exploring the current difficulties of e-education during the Covid-19 pandemic is outside the scope of this study. However, it seems that the current pandemic added a new layer of challenges that needs to be carefully examined in future research (Bao, 2020; Rapanta et al., 2020; Rose, 2020, p. 19; Sahu, 2020).

On the other hand, it was clear that SEU students perceive e-education as a tool that enhances their overall performance. This positive effect of e-education on the overall performance is in line with Diab \& Elgahsh's findings who reported that e-education has led to the enhancement of the overall students' performance during the Covid-19 pandemic (Diab \& Elgahsh, 2020). Even before the pandemic, several studies have reported better performance using e-education methods compared to conventional methods (Akugizibwe \& Ahn, 2020; Dodiya et al., 2019; Lumadi, 2013). However, a large meta-analysis study in 2019 found the effect of the flipped classroom to be moderate on students' performance and recommended further research to explore it (Strelan et al., 2020).

The current study has limitations. First, it only reflects the student's perspective regarding education and it does not include an academic staff point of view. In addition, the current study was based on self-perceived data. Results would be more precise if they were combined with other documented resources of data such as students' performance scores. Due to the cross-sectional nature of this study, the causality between e-education and the educational outcome could not be assessed. Also, the convenient sample methodology could be considered as one of the weak points of this study. However, the sample size could be considered as relatively large, which could increase the precision of study parameters. To the best of our knowledge, this was the very first study to examine the role of e-education in preserving educational outcomes during the Covid-19 pandemic on students enrolled in an electronic university in the Middle East Region.

\section{Conclusion}

In conclusion, the results of the current study revealed that the e-education method has a positive effect on educational outcomes during the Covid-19 pandemic. However, the challenges of e-education during the pandemic needs to be explored and addressed by the stakeholders of the e-education process. Also, there is a need for further longitudinal research to examine the long-term effects e-education of students' performance and their overall achievement.

One of the main recommendations of this study is to encourage finding motivation and monitoring tools to encourage the students to participate more in the online discussion, which could eventually enhance the 
achievement of students enrolled in the e-education.

It was clear that the SEU students prefer e-education to the traditional educational methods; however, more support is needed to eliminate challenges associated with the Covid-19 pandemic and maintain students' positive view towards the e-education process.

\section{References}

Akugizibwe, E., \& Ahn, J. Y. (2020). Perspectives for effective integration of e-learning tools in university mathematics instruction for developing countries. Education and Information Technologies, 25(2), 889-903. https://doi.org/10.1007/s10639-019-09995-z

Alawamleh, M., Al-Twait, L. M., \& Al-Saht, G. R. (2020). The effect of online learning on communication between instructors and students during Covid-19 pandemic. Asian Education and Development Studies, ahead-of-print(ahead-of-print). https://doi.org/10.1108/AEDS-06-2020-0131

Alfawaz, K. M., \& Yamin, M. (2020). AN EMPIRICAL STUDY OF EFFECTIVENESS OF E-LEARNING IN KING ABDULAZIZ UNIVERSITY. International Women Online Journal of Distance Education, 9(1), 1.

Almaghaslah, D., \& Alsayari, A. (2020). The Effects of the 2019 Novel Coronavirus Disease (Covid-19) Outbreak on Academic Staff Members: A Case Study of a Pharmacy School in Saudi Arabia. Risk Management and Healthcare Policy, 13, 795-802. https://doi.org/10.2147/RMHP.S260918

Alqahtani, A. Y., \& Rajkhan, A. A. (2020). E-Learning Critical Success Factors during the Covid-19 Pandemic: A Comprehensive Analysis of E-Learning Managerial Perspectives. Education Sciences, 10(9), 216. https://doi.org/10.3390/educsci10090216

Alsadoon, H. (2020). Obstacles to Using E-Books in Higher Education. International Journal of Education and Literacy Studies, 8(2), 44. https://doi.org/10.7575/aiac.ijels.v.8n.2p.44

Bao, W. (2020). Covid - 19 and online teaching in higher education: A case study of Peking University. Human Behavior and Emerging Technologies, 2(2), 113-115. https://doi.org/10.1002/hbe2.191

Baticulon, R. E., Alberto, N. R. I., Baron, M. B. C., Mabulay, R. E. C., Rizada, L. G. T., Sy, J. J., Tiu, C. J. S., Clarion, C. A., \& Reyes, J. C. B. (2020). Barriers to online learning in the time of Covid-19: A national survey of medical students in the Philippines [Preprint]. Medical Education. https://doi.org/10.1101/2020.07.16.20155747

Bayeck, R. Y. (2016). Exploratory study of MOOC learners' demographics and motivation: The case of students involved in groups. Open Praxis, 8(3), 223-233. https://doi.org/10.5944/openpraxis.8.3.282

Betron, M., Gottert, A., Pulerwitz, J., Shattuck, D., \& Stevanovic-Fenn, N. (2020). Men and Covid-19: Adding a gender lens. Global Public Health, 15(7), 1090-1092. https://doi.org/10.1080/17441692.2020.1769702

Boateng, J. K. (2015). Adults Pursuing E-Learning in Ghana - Opportunities, Challenges and Expectations. Journal of Education and E-Learning Research, 2(4), 64-71.

Bugis, B. (2020). Employing Blended Learning Health Sciences Graduates in Saudi Arabia: Community Preceptors' Evaluation of Interns [Preprint]. In Review. https://doi.org/10.21203/rs.3.rs-27276/v1

Coronavirus Outbreak Forces Arab Countries to Consider Long-Ignored Online Education. (2020, March 12). AlFanar Media. https://www.al-fanarmedia.org/2020/03/coronavirus-outbreak-forces-arab-countries-toconsider-long-ignored-online-education/

Devisakti, A., \& Ramayah, T. (2019). E-Learning Usage Outcomes among University Learners: A Pilot Study. Journal of Education and E-Learning Research, 6(3), 149-155. https://doi.org/10.20448/journal.509.2019.63.149.155

Diab, G. M. A. E.-H., \& Elgahsh, N. F. (2020). E-learning During Covid-19 Pandemic: Obstacles Faced Nursing Students and Its Effect on Their Attitudes While Applying It. American Journal of Nursing, 9(4), 300-314.

Dodiya, D., Vadasmiya, D., \& Diwan, J. (2019). A comparative study of flip classroom teaching method versus traditional classroom teaching method in undergraduate medical students in physiology. National Journal of Physiology, Pharmacy and Pharmacology, 0, 1. https://doi.org/10.5455/njppp.2019.9.0310829032019

ESRI, Mohan, G., McCoy, S., ESRI, Carroll, E., ESRI, Mihut, G., ESRI, Lyons, S., ESRI, Mac Domhnaill, C., \& ESRI. (2020). Learning for all? Second-level education in Ireland during Covid-19. ESRI. https://doi.org/10.26504/sustat92.pdf

Kaur, N., Dwivedi, D., Arora, J., \& Gandhi, A. (2020). Study of the effectiveness of e-learning to conventional teaching in medical undergraduates amid Covid-19 pandemic. National Journal of Physiology, Pharmacy and Pharmacology, 10(7), 1. https://doi.org/10.5455/njppp.2020.10.04096202028042020

Khalil, R., Mansour, A. E., Fadda, W. A., Almisnid, K., Aldamegh, M., Al-Nafeesah, A., Alkhalifah, A., \& AlWutayd, O. (2020). The sudden transition to synchronized online learning during the Covid-19 pandemic in Saudi Arabia: A qualitative study exploring medical students' perspectives. BMC Medical Education, 20(1), 285. https://doi.org/10.1186/s12909-020-02208-z

KSA, M. of H. (2020, July 10). How to protect yourself from Covid-19? Protect against Covid-19. https://dev135.covid19awareness.sa/en/home-page 
Linjawi, A. I., Walmsley, A. D., \& Hill, K. B. (2012). Online discussion boards in dental education: Potential and challenges: Online discussion boards. European Journal of Dental Education, 16(1), e3-e9. https://doi.org/10.1111/j.1600-0579.2010.00662.x

Lumadi, M. W. (2013). E-learning's impact on the academic performance of student-teachers: A curriculum lens. Mediterranean Journal of Social Sciences, 4(14), 695-695.

Martins, M. D., Carrard, V. C., dos Santos, C. M., \& Hugo, F. N. (2020). Covid - 19-Are telehealth and tele education the answers to keep the ball rolling in Dentistry? Oral Diseases, odi.13527. https://doi.org/10.1111/odi.13527

Network, A. A. (2020, March 2). Saudi Arabia reports first coronavirus case, a Saudi national coming from Iran. Al Arabiya English. https://english.alarabiya.net/en/News/gulf/2020/03/02/Saudi-Arabia-reports-firstcoronavirus-case-state-media.html

Nguyen, T., \& Huynh, N. (2020). Impact of the Covid-19 Pandemic Outbreak on the Learning Process [Lapland University of Applied Sciences]. https://www.theseus.fi/handle/10024/340971

Rajhans, V., Memon, U., Patil, V., \& Goyal, A. (2020). Impact of Covid-19 on academic activities and way forward in Indian Optometry. Journal of Optometry, S1888429620300558. https://doi.org/10.1016/j.optom.2020.06.002

Rapanta, C., Botturi, L., Goodyear, P., Guàrdia, L., \& Koole, M. (2020). Online University Teaching During and After the Covid-19 Crisis: Refocusing Teacher Presence and Learning Activity. Postdigital Science and Education. https://doi.org/10.1007/s42438-020-00155-y

Rose, S. (2020). Medical Student Education in the Time of Covid-19. JAMA, 323(21), 2131. https://doi.org/10.1001/jama.2020.5227

Sahu, P. (2020). Closure of Universities Due to Coronavirus Disease 2019 (Covid-19): Impact on Education and Mental Health of Students and Academic Staff. Cureus, 12(4), e7541. https://doi.org/10.7759/cureus.7541

Sapkota, P. P., \& Narayangarh, C. (2020). Determining Factors of the Use of E-learning during Covid-19 Lockdown among the college students of Nepal: A Cross-Sectional Study. A Mini Research Report, Balkumari College, Narayangarh, Chitwan, Nepal ....

Saudi Electronic University, S. (2020). Saudi Electronic University (SEU)—History and Timeline. https://seu.edu.sa/en/about/

Saudi Electronic University, W. (n.d.). E-learning initiative. Retrieved September 18, 2020, from https://seu.edu.sa/sr/ar/e-learning-initiative/

Strelan, P., Osborn, A., \& Palmer, E. (2020). The flipped classroom: A meta-analysis of effects on student performance across disciplines and education levels. Educational Research Review, 30, 100314. https://doi.org/10.1016/j.edurev.2020.100314

Taunton, Y. (2020, August 9). How has Covid-19 affected the way we communicate? UAB News. https://www.uab.edu/news/research/item/11542-how-has-covid-19-affected-the-way-we-communicate

Williams, J. R. (2008). The Declaration of Helsinki and public health. Bulletin of the World Health Organization, 86, 650-652.

WorldAware. (2020, April 13). Covid-19 Alert: Saudi Arabia Extends Nationwide Curfew From April 12 Until Further Notice. WorldAware. https://www.worldaware.com/covid-19-alert-saudi-arabia-extendsnationwide-curfew-april-12-until-further-notice

Zhong, Z. (2020). Research on the influence of remedial measures on public satisfaction after government information service failures in typhoon disasters: A case from China. Ocean \& Coastal Management, 190, 105164. https://doi.org/10.1016/j.ocecoaman.2020.105164 
The perception of e-education is superior to traditional education in the learning process

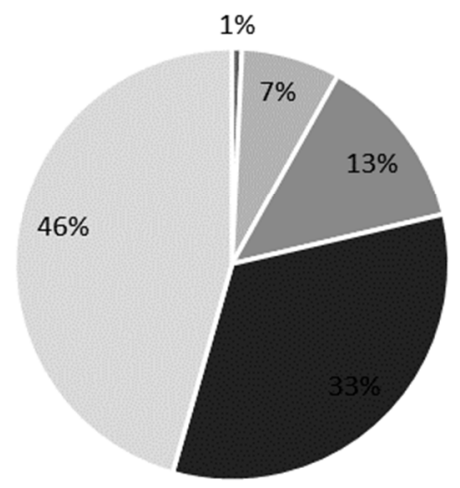

- Strongly Disagree

m Disagree

- Nutral

- Agree

Strongly Agree

Figure 1. The perception of e-education is superior to traditional education in the learning process

Table 1. Study Questionnaire

\begin{tabular}{|c|c|}
\hline Gender & $\begin{array}{ll}\cdot & \text { Male } \\
\text { - } & \text { Female }\end{array}$ \\
\hline Age & $\begin{array}{ll}\cdot & 18-20 \\
\cdot & 21-23 \\
\cdot & 23+\text { years }\end{array}$ \\
\hline $\begin{array}{l}\text { How many hours do you use e-education tools } \\
\text { per week? }\end{array}$ & $\begin{array}{ll} & \text { Less than an hour } \\
\text { - } & 1-7 \text { hours } \\
\text { - } & 7-14 \text { hours } \\
\text { - } & 14+\text { hours }\end{array}$ \\
\hline
\end{tabular}

Please select the answer that best fits your feeling (Strongly Disagree, Disagree, Neutral, Agree, Strongly Agree)

1. I believe it is appropriate to use e-education for my university study

2. I am confident in using e-education tools

3. I am positive towards using e-education tools for my daily study

4. The academic employees at SEU support the use of e-education for my study

5. Other students' beliefs about e-education encourage me to continue using e-education

6. My family encourages me to continue using e-education

7. E-education contents are informative

8. I participate in online discussions with professors and other students

9. I can overcome challenges that occur when I use e-education

10. I tend to finish the courses I registered to

11. Using e-education improves my overall performances

12. E-education encourages me to explore additional information in my area of study

13. Using e-education improves my effectiveness in managing my time

14. E-education decreases students educational expenses

15. E-education is superior to traditional education in the learning process

16. I recommend using e-education for others 
Table 2. Characteristics of study participants

\begin{tabular}{|c|c|c|c|c|}
\hline & & $\mathrm{n}$ & $\%$ & P-value of univariate analysis \\
\hline \multirow[t]{2}{*}{ Student gender } & Male & 80 & 58.8 & 0.049 \\
\hline & Female & 56 & 41.2 & $\begin{array}{l}\text { (There is a statistically significant difference in the } \\
\text { numbers of students according to their gender) }\end{array}$ \\
\hline \multirow[t]{3}{*}{ Student age } & $18-20$ & 65 & 48.1 & 0.001 \\
\hline & $21-23$ & 40 & 29.6 & \multirow{2}{*}{$\begin{array}{l}\text { (There is a statistically significant difference in the } \\
\text { numbers of students according to their age) }\end{array}$} \\
\hline & $23+$ years & 30 & 22.2 & \\
\hline \multirow{4}{*}{$\begin{array}{l}\text { Number of hours } \\
\text { using e-education } \\
\text { tools per week }\end{array}$} & Less than an hour & 37 & 26.8 & 0.724 \\
\hline & $1-7$ hours & 35 & 25.4 & \multirow{3}{*}{$\begin{array}{l}\text { (No significant difference in the percentage of the } \\
\text { students according to the duration of using e-education } \\
\text { tools per week) }\end{array}$} \\
\hline & $7-14$ hours & 37 & 26.8 & \\
\hline & $14+$ hours & 29 & 21.0 & \\
\hline
\end{tabular}

Table 3. Participants' perception of e-education

\begin{tabular}{|c|c|c|c|c|c|c|c|}
\hline \multirow[b]{2}{*}{ Variable } & \multicolumn{3}{|c|}{ Male students } & \multicolumn{3}{|c|}{ Female students } & \multirow{2}{*}{$\begin{array}{l}\mathrm{p}- \\
\text { value }\end{array}$} \\
\hline & $\mathrm{N}$ & Mean & SD & $\mathrm{N}$ & Mean & SD & \\
\hline Using e-education for my university study is appropriate & 80 & 2.9 & 1.2 & 56 & 2.7 & 1.3 & 0.510 \\
\hline Confidence in using e-education tools & 79 & 2.5 & 1.4 & 55 & 2.2 & 1.5 & 0.181 \\
\hline $\begin{array}{l}\text { Positive view towards using e-education tools for my daily } \\
\text { study }\end{array}$ & 80 & 2.7 & 1.1 & 56 & 2.6 & 1.3 & 0.839 \\
\hline $\begin{array}{l}\text { The academic employees at SEU supportive to the use of e- } \\
\text { education }\end{array}$ & 80 & 2.5 & 1.4 & 55 & 2.3 & 1.4 & 0.242 \\
\hline Encourage other students to use e-education tools & 79 & 2.4 & 1.4 & 54 & 2.0 & 1.5 & 0.099 \\
\hline Family members encourage the use of e-education & 79 & 2.0 & 1.3 & 53 & 1.9 & 1.4 & 0.700 \\
\hline E-education contents are informative & 80 & 2.3 & 1.4 & 54 & 2.7 & 1.3 & 0.093 \\
\hline $\begin{array}{l}\text { Students participation in online discussions with professors } \\
\text { and other students }\end{array}$ & 80 & 2.1 & 1.5 & 55 & 2.2 & 1.5 & 0.637 \\
\hline Overcoming challenges that occur when using e-education & 79 & 1.8 & 1.4 & 54 & 2.0 & 1.4 & 0.506 \\
\hline Finishing registered e-education courses & 80 & 2.3 & 1.4 & 55 & 2.6 & 1.5 & 0.161 \\
\hline E-education improves the overall performance & 80 & 3.0 & 1.2 & 55 & 3.1 & 1.1 & 0.787 \\
\hline $\begin{array}{l}\text { E-education encourages the exploration of additional } \\
\text { information in areas of study }\end{array}$ & 80 & 2.1 & 1.4 & 54 & 1.8 & 1.5 & 0.385 \\
\hline $\begin{array}{l}\text { Using e-education improves the effectiveness of time } \\
\text { management }\end{array}$ & 79 & 2.1 & 1.4 & 56 & 1.8 & 1.5 & 0.204 \\
\hline E-education decreases students educational expenses & 78 & 2.4 & 1.3 & 56 & 2.4 & 1.4 & 0.956 \\
\hline $\begin{array}{l}\text { E-education is superior to traditional education in the } \\
\text { learning process }\end{array}$ & 78 & 3.1 & 0.9 & 56 & 3.2 & 1.0 & 0.341 \\
\hline Recommendation of e-education to other & 78 & 2.5 & 1.3 & 56 & 2.5 & 1.4 & 0.983 \\
\hline
\end{tabular}

Table 4. The overall perception of education at SEU

\begin{tabular}{|c|c|c|c|c|c|c|}
\hline & \multicolumn{2}{|c|}{ Positive perception } & \multicolumn{2}{|c|}{ Negative perception } & \multirow[t]{3}{*}{ p-value } \\
\hline & & $\mathrm{n}$ & $\%$ & $\mathrm{~N}$ & $\%$ & \\
\hline \multicolumn{2}{|l|}{ Overall } & 59 & 42.8 & 79 & 57.2 & \\
\hline \multirow[t]{3}{*}{ Age (in years) } & $18-20$ & 25 & 38.5 & 40 & 61.5 & \multirow[t]{3}{*}{0.546} \\
\hline & $21-23$ & 18 & 45.0 & 22 & 55.0 & \\
\hline & $23+$ years & 15 & 50.0 & 15 & 50.0 & \\
\hline \multirow[t]{2}{*}{ Gender } & Male & 36 & 45.0 & 44 & 55.0 & \multirow[t]{2}{*}{0.507} \\
\hline & Female & 22 & 39.3 & 34 & 60.7 & \\
\hline \multirow{4}{*}{$\begin{array}{l}\text { Number of hours using } \\
\text { e-education tools per } \\
\text { week }\end{array}$} & Less than an hour & 13 & 35.1 & 24 & 64.9 & \multirow[t]{4}{*}{0.497} \\
\hline & $1-7$ hours & 18 & 51.4 & 17 & 48.6 & \\
\hline & $7-14$ hours & 17 & 45.9 & 20 & 54.1 & \\
\hline & $14+$ hours & 11 & 37.9 & 18 & 62.1 & \\
\hline
\end{tabular}

